\title{
FOUR GLANCES AT THE FEAST OF THE ASSUMPTION: THE HOLIDAY THROUGH SPACE AND TIME
}

\author{
Žilvytis Šaknys \\ Department of Ethnology and Anthropology, Lithuanian Institute of History, \\ Vilnius, Lithuania \\ e-mail:shaknys@gmail.com
}

\begin{abstract}
In my article, I attempt to track the ritual year in different social and cultural settings. The Feast of the Assumption was chosen for this research as a traditional religious holiday in Lithuania. Various chronological periods and localities of the feast are under investigation: celebrations in the $19^{\text {th }}$ to the first half of the $20^{\text {th }}$ centuries; the Assumption as a Lithuanian national holiday in 1929 in Kaunas; the Feast as a Lithuanian holiday specifically celebrated in Punsk (North Poland) since 1967; and finally, as a non-working day in Vilnius and Vilnius environments since 2000. The comparison of these versions, forms, and meanings of the Assumption leads to the conclusion that even a religious holiday can embody different values in different sociocultural surroundings, ranging from religious, national, and ethnic significance, to simply an excuse for a day off from work.
\end{abstract}

Keywords: Feast of the Assumption, holiday, religiosity, Ritual year, secularity, values

\section{Introduction}

As Amitai Etzioni has said, "the editing and the limited re-engineering of holidays (rituals included) take place constantly, drawing on both new designs and 
old patterns. How effective it is, and how effective it can be, is a major subject for social scientists, as it currently remains largely unstudied" (Etzioni 2004: 6). In my article, I make an attempt to track the ritual year in different social and cultural settings. The Feast of the Assumption as a traditional religious holiday of the $19^{\text {th }}$-first half of the $20^{\text {th }}$ centuries in Lithuania; as a Lithuanian national holiday in 1929 in Kaunas; as a Lithuanian holiday specifically celebrated in Punsk (North Poland) since 1967; and as a non-working day in Vilnius and Vilnius environments from 2000 was chosen for this research.

Several stages can be discerned when analyzing the ritual year in Lithuania, as in other post-socialist countries. In the first stage, from 1918 when the modern Lithuanian state was created, religious holidays associated with the Church predominated. However, besides the liturgical element, there were also folk forms of entertainment that functioned in the Christian context of the celebration (Mardosa 2013: 58). In the second stage - in 1940-1941, and especially in 1944-1990, we notice fundamental changes that were unprecedented in Lithuania, where, as Catherine Bell said, "The new rites would replace older religious rites as communist morality and socialist internationalism would overpower bourgeois nationalism. Special commissions researched both general and local issues, devised systematic descriptions of particular rites, and gave practical assistance to those attempting to implement the rites on the local level" (Bell 1997: 226-227). The third stage, which Lithuania's ethnologists have not yet properly evaluated, sees the "revitalisation" of old holidays in the formation of the "religious" ritual year. However, according to the ethnologist Petras Kalnius, we are living in a period when "more and more people accept God, but seek salvation through short-term obligations outside the Church sphere, where they promote 'non-religious Christianity"' (Kalnius 2003: 186). In some cases, the holiday can embody different values in different social and cultural contexts, and have a radically different relationship with religiosity. I have already written on this theme when analysing Shrovetide in Lithuania (Užgavenes), revealing this celebration as an agrarian, urban, socialist, and a "Lithuanian" holiday celebrated in emigrant families (Šaknys 2015a: 105-128). However, as a holiday, Shrovetide is not notable for its religious content and is only one day before the Lent period. Another type of holiday is the Feast of the Assumption (Žolines), which has a clear and defined link to religion with its main rituals being carried out in the church. I have chosen the Feast of the Assumption for my study, since I intend to analyze whether a religious holiday can take on a secular form in a different social and cultural environment. 
In Lithuania, this holiday is not celebrated by people of all confessions. Out of the larger confessions functioning in Lithuania, the holiday is important to Catholics (the dominant faith in Lithuania by number of followers), the Christian Orthodox, and the Old Believers. Back in the early $20^{\text {th }}$ century, the Feast of the Assumption was celebrated at the state level. In the beginning of the $20^{\text {th }}$ century, when most of Lithuania belonged to the Russian Empire, the Feast of the Assumption was not a regular work day; in 1918, this status quo remained in place when Lithuania regained its independence. However, when, in 1915, the Gregorian calendar was adopted, the Assumption was celebrated on August $15^{\text {th }}$ by Catholics, while the Christian Orthodox and the Old Believers kept adhering to the Julian calendar and therefore celebrated the Feast of the Assumption twelve days later (Šaknys 2015b: 103).

My research on the Feast of the Assumption is based on personal field research conducted at different periods. Material about the traditional Christian calendar holidays was selected from various locations in Lithuania ranging from 1988 to 1995. The traditional and modern customs alive in the Punsk (North Poland) area were analyzed in 1989 and 2005. Today's situation was documented by conducting research on the leisure time and holidays in the daily life of Vilnius and the Vilnius surroundings, in 2012-2016 and in 2017-2018, respectively. A semi-structured interview was not the only method used; while living in Vilnius at various periods, I had the opportunity to observe this celebration in Vilnius city, and in 1989, I observed how the Assumption was celebrated in Punsk. Press publications (the main source when analyzing the situation in 1929) and internet sources were also used. Ethnologists' research and the data they collected was also useful, especially the works by Maria Znamierowska-Prüfferowa (Znamierowska-Prüfferowa 1997; 2009), Angelè Vyšniauskaitė (Vyšniauskaitė 1993), Nijolè Marcinkevičienė (Marcinkevičienė 1998), Aldona Vaicekauskienè (Vaicekauskienè 2004: 3-22) and Jonas Mardosa (Mardosa 2004: 93-112; Mardosa 2007: 155-168; Mardosa 2016a: 53-67; Mardosa 2016b: 291-311).

\section{The Feast of the Assumption as a Religious Holiday}

The celebration of the Assumption in the Christian liturgical year was established in religious documents in the first centuries of Christianity. The custom of the consecration of herbs, common to the Feast of the Assumption of the Virgin Mary into Heaven, started in the $10^{\text {th }}$ century; details on the prayers of 
the consecration of flowers, in which God is asked for the herbs to be beneficial both to the healthy and to the ill, to humans and to animals, are well-know to us. This tradition reached Lithuania along with Christianity; similar prayers can be found in $17^{\text {th }}$ century Roman Catholic Church documents (Mardosa 2016b: 309).

This day was also related to folk beliefs associated with the end of the most important field work, and with the juncture of summer and autumn. The Lithuanian name for this holiday (Žoline 'grass day') confirms this association. In South Lithuania (Dzūkija), Žoline, the Feast of the Assumption, was also known as Kopūstine ('cabbage day'). Apart from flowers, in the late $19^{\text {th }}$ - early $20^{\text {th }}$ centuries, the first fruits and vegetables of the season would also be brought to the church to be blessed. For example, in South Lithuania the bouquet would also have a carrot, turnip, peas, beetroot, and a head of cabbage (Vyšniauskaite 1993: 106). Rye, wheat, and oats would also be sanctified, and these grains would be mixed with all the grains before sowing for a better harvest (Šaknys 2007: 129). All members of the family would eat these blessed vegetables and would share them with their livestock to protect them against disease. Dried grass would be kept in the cottage tucked behind pictures of saints, and during thunderstorms, this grass would be set alight, allowing the smoke to waft around inside; the ill would drink tea brewed with this particular grass (Vyšniauskaite 1993: 106). Certain restrictions regarding food were also associated with the day of the Assumption. Women who had lost at least one child were not allowed to eat apples until the day of the Assumption had come. During expeditions into various regions around Lithuania, I also heard stories about how mothers who did not abide by this restriction (several women spoke about their own personal experiences) would have dreams about their deceased child, who complained that it was her fault that God did not give him any apples, because his mother had already eaten them. As a result, women from various regions around Lithuania who had lost children strictly followed this prohibition. When writing about the customs alive in the Vilnius surrounds, ethnologist Maria Znamierowska-Prüfferowa mentioned that for the same reasons, women would not eat carrots, beetroot, cabbage, pears, and even potatoes, believing that God gave fruit only to those deceased children whose mothers restrained from eating them until the day of the Assumption (Znamierowska-Prüfferowa 2009: 196). In some areas, the same prohibitions were followed, only that it was the Virgin Mary who shared and gave out the fruit in heaven, not God (Marcinkevičienè 1998: 124-125). The grass blessed 
during the Assumption celebrations also performed a specific function in funeral customs. Even today, there is a custom where the grass is placed in a coffin (inside the pillow or underneath the body of the deceased) (Mardosa 2016b: 300-301). In some areas in South Lithuania, people would still give alms to beggars in the early 20th century. On that day, meals would be prepared from that year's harvest. Everything that was set aside for beggars would be placed on the table - a mutton leg, several loaves of bread, or cake. Then the head of the household would light a candle, say the Litany of the Saints, and pass it around the food set aside for the beggars three times. After breakfast, the family would go to church and give this food to beggars near the church or leave it at a shelter (Lit. Špitole from Ger. Spital, an early form of 'hospital') for distribution (Marcinkevičienė 1998: 125).

These examples show us that in the late $19^{\text {th }}$ to the first half of the $20^{\text {th }}$ centuries, the Feast of the Assumption was an important religious holiday in the agrarian community, though not as significant as Christmas, Easter, or Pentecost, which were celebrated for two to four days, nor did it lead to secular entertainment that would gather all the people from the village (shared feasting, walking around together, swinging on large swings, etc.). The Feast of the Assumption was purely a celebration for farmers, and we shall analyse whether it had the same significance in the city as a state holiday in the next section, by looking at how it was celebrated in the temporary capital of Lithuania, Kaunas (the Lithuanian capital Vilnius was under Polish occupation in the years 1920-1939).

\section{The Feast of the Assumption as a National Holiday}

The concept of the "National Day" was used in Lithuania in the years 1918-1940 to identify the most important state holiday. However, over time, the "National Day" title was also given to a range of different celebrations: the day of the Declaration of Independence of the Lithuanian state (February $16^{\text {th }}$ ), the day when the Constituent Assembly gathered (May 15 $5^{\text {th }}$ ), the Feast of the Assumption (August $15^{\text {th }}$ ), and the day of the coronation of the Grand Duke of Lithuania, Vytautas the Great (September $8^{\text {th }}$ ). Over the perspective of time, the significance of these holidays changed due to political circumstances (Šaknys 2018: 129-154). A surprising decision was reached in 1929; on August $14^{\text {th }}$, 1929, an important Lithuanian state newspaper, Lietuvos aidas, featured the following information: "Tomorrow we shall be marking the National Day. Our 
government has combined all national and state holidays into one national holiday, giving it one day, August $15^{\text {th }}$, which is a church feast day" (Tautos švente 1929: 1). This holiday was described in a similar way in the Lithuanian military weekly Karys (karys 'soldier'): "August $15^{\text {th }}$ is a major holiday for us because it incorporates the ceremony set aside for February $16^{\text {th }}$ - our great military parade - and May $15^{\text {th }}$, and the fine autumn, the Feast of the Assumption, church holiday that is celebrated so widely and nicely by our people" (Kpt. Balčiūnas 1939: 531). So, this National Holiday had combined three occasions into one. A strange motive was given as the foundation for this decision; the Feast of the Assumption was announced as the National Holiday in 1929 in the lead article in the Lietuvos aidas newspaper, stating that it was more convenient to celebrate this occasion in the summer rather than on February $16^{\text {th }}$, while May $15^{\text {th }}$ was a busy time due to all the spring-time related work. August $15^{\text {th }}$ was the most convenient day for the National Holiday, which was also a Church holy feast day, and thus it had to be celebrated as such, and not increase the number of days off from regular work (Tautos šventè 1929: 1). It appears that this was important to Lithuania in light of the global economic crisis, however, "the combination of all national and state holidays" could hardly have created one holiday and its respective rituals. At least in Kaunas, its seasonality was not very evident. As was the case with all major state holidays, it began the day before by expressing respect for the nation's dead heroes. The morning of the holiday would begin with a parade, followed by mass held at church later in the day, the president of the Republic of Lithuania would give a speech and there would be a military parade. The city would be illuminated with lots of lights (Kriaukeniškis 1929: 3). As such, the holiday was not as modest and inexpensive as one would expect, given the conditions of a global economic crisis. On the other hand, it is difficult to understand how the Feast of the Assumption - the day when the Blessed Virgin Mary was taken up into Heaven - could have satisfied the population from the Klaipeda Region that had recently been incorporated into Lithuania (1923), most of whom were Evangelical Lutherans. Nor is it likely that the Assumption, as the most important state holiday, could have been accepted by other people who did not profess the Catholic faith (as was already mentioned, the Orthodox and the Old Believers who marked this holiday did so on a different date). It shows that the artificially formed seasonal aspect of this holiday would not necessarily become the basis for a successful ritual. On the other hand, this was the only and the most important national holiday that had no links to events considered important to the state, and was 
thus difficult for society to comprehend. It could be said that the experiment of combining a religious and a secular celebration into one did not succeed. In 1930 , this National Day was changed to a new date, September $8^{\text {th }}$, which commemorated the failed coronation of the Grand Duke of Lithuania Vytautas in 1430, as well as a religious celebration - the Nativity of the Blessed Virgin Mary (Sirutavičius 2001: 134).

\section{The Feast of the Assumption as a Holiday for Lithuanians in Punsk}

The public commemoration of the Feast of the Assumption as a religious or Lithuanian national holiday under the conditions of Soviet atheism and internationalism was not possible in Soviet Lithuania. Even in the case of religious feast days, the holiday would be moved to a weekday, and people who held important positions in the education or culture spheres would place their careers at risk by participating. However, there were exceptions in the neighbouring socialist countries. The significance of the Assumption as a religious and national holiday was combined with a feast day ordinarily celebrated in the Punsk parish. The parish, which consists mostly of Lithuanians, belonged to the People's Republic of Poland, where atheist policies were not expressed so intensively. The situation of Punsk, as a remote provincial Polish town, increased the local population's opportunities to organize public events and even express national views during religious celebrations.

According to the research of ethnologist Aldona Vaicekauskiene, the Assumption folk traditions alive in the Punsk area were similar to those in South Lithuania. It was believed that grass blessed on the Assumption would offer protection from thunderstrikes, it was used to cure children of being scared, women would prepare bouquets of this grass to be placed in their coffins for the day when they died. Blessed stalks of rye, barley, and wheat would be scattered into grains for sowing to protect them against hail and drought, and to ensure a better harvest (Vaicekauskienè 2004: 9). However, besides being just a religious feast day, this holiday had other types of activity. One of the most important elements were Assumption Day wreaths. Algis Uzdila presents a brief history:

The Feast of the Assumption is a special celebration in the Punsk parish. It started being celebrated in a particular way in the times of Fr Ignas Dzermeika. The priest, who was very experienced and had a broad 
imagination, arrived in Punsk in 1967 and started organising the making of the wreaths for the Assumption holiday. Among the first to show their enthusiasm were the villagers from Vaitakiemis, or more precisely, the young people there, who included some active students. Other neighbours followed their example. Up until then, women would go to church with bouquets of flowers, but these started being replaced by artistic small altar-type creations - Assumption Day wreaths. Word spread about these wreaths, tourists became interested in the new phenomenon and kept arriving in ever larger crowds. Photographers and filmmakers also came. Punsk began to attract more and more attention (Uzdila 2005: 18).

During the first years these Assumption Day wreaths were made, parish villages inhabited by Poles also participated, though later on, only the Lithuanians kept up this tradition (Svidinskaite 2006: 245). The wreaths often embodied national symbolism. In 1967, a wreath made by someone in Vaitakiemis even incorporated the Gediminid Columns made from the upper grain stalks, thin wire was used to attach a Vytis cross, while a wreath from 1988 featured the Vytis, and in 1991, in memory of the bloody events of January in Lithuania, one wreath had a heart pierced with arrows. When the survival of the Lithuanian parish in Vidugiriai (a village near Punsk) was threatened, a wreath was made depicting a model of its church with its doors locked (Vaicekauskiene 2004: 9). Symbols of the Gediminid Columns and the Vytis cross were not tolerated in the Lithuanian SSR and were strictly banned in the public religious and secular space until 1988. The act of making these wreaths in the past was, and today is, usually the domain of younger people. The Assumption retains certain features of a traditional celebration; after a ceremonial procession, the wreaths would be placed in church; after several weeks, each village would take back their wreaths and divide the grains among the wreath-makers. According to tradition, everyone would add these grains to those set aside for sowing, or feed them to their livestock or chickens. Some believed this would ensure a good harvest or success in breeding heads of cattle. On the other hand, a number of innovations were also present in how the Assumption was celebrated in Punsk. Fairs were held starting in 1983 with a festive program; and starting in 2000, folklore ensembles were invited to perform. From 2004, the Bread, Honey, and Milk Festival also started being held to coincide with the Feast of the Assumption (Vaicekauskiene 2004: 3-22). In 2019, the Assumption holiday lasted for five days. However, the celebration was only related to religion on August $15^{\text {th }}$, 
from 8:00 a.m. to 2:00 p.m. (three mass services, the blessing of the wreaths, praying the Rosary, and a ceremonial procession). The rest of the time was dedicated to performances by local Lithuanian folklore ensembles, or ones that had arrived for this occasion from Lithuania, traditional and modern music concerts, theatrical performances, dances, a folk artists' market, and the Bread, Honey and Milk Festival (Žolines Punske). By attracting Lithuanian musicians and other cultural activists, traders and tourists from Lithuania, the people of Punsk truly made this a "Lithuanian holiday". It became hugely popular among young people. I was convinced of this when watching the celebrations back in 1989. There was not a single person in Punsk who had ignored the holiday or said it was not important to them. In 2005, during other field research, I asked respondents aged 17-19 from around the Punsk area ( 43 semi-structured interviews) to name their favourite holiday. "The Feast of Assumption" was named as their second-favourite holiday, after Christmas. Explaining their choices, the young people listed the holiday's events, highlighting how they happily spent time with their friends and especially the "Lithuanian music" aspect (Šaknys 2009: 90). Thus, this is an example of a successful attempt at giving a secular form to a religious holiday.

Let us now look at how a similar task has been handled in recent years on a state-wide scale in the Lithuanian capital of Vilnius and in surrounding villages, towns, and cities where, like in Punsk, the religiosity of people is greater than the average in other places in Lithuania.

\section{The Modern "Assumption Day" Holiday in Vilnius and Its Surrounds}

In order to understand the modern "Assumption Day" holiday, we should look back to some holidays of the Soviet period. From the very beginning of the occupation (1940-1941; 1944-1989), Soviet authorities changed the entire system of calendar holidays in Lithuania. In the entire Soviet Union, revolutionary festivals were marked as official holidays. The period under the Soviet regime was a time when new traditions were being reinvented. New 'socialist', 'communist', or even 'new life' traditions were created, with the intention to replace the old ones that embodied religious beliefs. Therefore, during the Soviet period, in many cases, the family remained on the sidelines of ideologically transformed holidays and was able to preserve a significant portion of the old 
traditions (Paukštytè-Šaknienè 2016: 31-34). However, we cannot dismiss natural modernisation or secularisation processes that had an impact in Soviet Lithuania, and even after independence was reinstated after 1990. According to Laurent Sébastien Fournier (2019), the word festival remains because of its positive values, but the content has dramatically changed as festivals have adapted to a new world in which the family and the community have been replaced by the media and the market.

Specific conditions were created for "Assumption Day" in Lithuania, on account of it being a religious celebration. It was declared a state holiday in 2000 , giving it the status of a non-working day. When analysing how the Feast of the Assumption is celebrated today, particularly in Vilnius by Lithuanians, Poles, and Russians, Jonas Mardosa noticed that the holiday's transformation into a truly significant day in the state holiday calendar became a theoretical and practical problem for the city (Mardosa 2016b: 292). Its status does not raise any problems for those faithful who have preserved the same religious understanding of the holiday of the Blessed Virgin's ascent into Heaven, and the day off from work allows them to actively participate in the liturgy, which has not changed over time (Mardosa 2016b: 295). For non-believers or those who do not associate the Feast of the Assumption with a state holiday, like for Orthodox believers who celebrate their "Assumption Day" on August $28^{\text {th }}$, it is simply an additional day off from work that does not have a place in their concept of celebration (Mardosa 2016b: 305). According to the ethnologist's research data, as many as 42.4 percent of Lithuanians, 40.3 percent of Russians, and 26.7 percent of Poles do not understand the meaning of the holiday (Mardosa 2016b: 296).

As part of my own research data collected in 2016-2017, I asked young residents of Vilnius whether they celebrated this occasion with their family, with friends, with co-workers, or not at all. I also asked them to name three of the calendar holidays they identified most with their friends (40 semi-structured interviews). A total of 67.5 percent of respondents did not celebrate "Assumption Day" at all, 12.5 percent celebrated it with their family, 15 percent with friends, and 4.5 percent with co-workers. One respondent took the opportunity to travel (to Denmark) with friends, others spent it at a farmstead with university friends, at a village, or with their families. Incidentally, 4.5 percent of respondents named "Assumption Day" as one of the three most important holidays spent with friends (Šaknys 2019: 256). According to its unpopularity among holidays that have been made official non-working days, the Feast of the Assumption 
competes against International Labour Day (82.5 percent of respondents did not celebrate this occasion) and the Coronation Day of Mindaugas, which was celebrated somewhat more often (57.5 percent of respondents did not mark this day). Even though these holidays often fall on a regular weekday (if it does not happen to be a Saturday or Sunday in a given year), in terms of its popularity this day is even surpassed by International Women's Day and St. Valentine's Day, which were not celebrated by only 32.5 and 42.5 percent of respondents, respectively. When asked why they did not celebrate the Feast of the Assumption, a majority of young people replied that they did not know how it was supposed to be celebrated, or in some cases, they explained that they were not religious and saw no reason for having to mark this day (Šaknys 2019: 256). This situation was confirmed at the Feast of the Assumption holiday mass held on August 15, 2019 at the Church of the Immaculate Conception of the Blessed Virgin Mary in Vilnius. Elderly people made up an absolute majority of those gathered, with but a few younger people. Nonetheless, there are a number of opportunities to happily mark this holiday in Vilnius and its surrounds.

Let us look at how the celebration of "Assumption Day" in 2019 was described in advertising websites. The residents of Vilnius were invited to Trakai (30 km away from Vilnius) to hold the Feast of the Assumption, and to attend the celebration organised for this occasion. Aside from mass in Lithuanian and Polish, to which people were encouraged to come dressed in national costumes and to bring healing herbs and grasses, flowers, grains, and vegetables to be blessed, and which would then be used as part of the ceremonial procession, there was also going to be a non-religious "Kopūstine" celebration where a number of folklore ensembles from Trakai and the neighbouring cities, as well as other art collectives would perform, followed by an educational program involving grass bouquet composition, saying spells, making bracelets, tying sashes, painting wooden flowers, and even carving wooden spoons. The celebration would end with a free tasting of cabbage soup. A free excursion titled "The Blossoms of Summer" was planned for the historical surrounds of Vilnius, plus a cultural program by the river, a film screening, and a special "Assumption Day" marathon around Vingis Park. An event was also planned at the Franciscan Church, a concert by the Jauti rock group for young people, and an open-air screening of a Charlie Chaplin film in the courtyard of the Palace of the Grand Dukes of Lithuania. Excursions into the countryside and forests were on offer, encouraging the public to admire the beauty of nature not far from Vilnius by taking the Grabijoliai walking track. Turgeliai, a town $33 \mathrm{~km}$ 
away from Vilnius, was organising the traditional religious feast day celebration and a concert. An event was also planned at the Centre of Europe Golf Club $60 \mathrm{~km}$ away from Vilnius, where people could try playing golf. A hemp-tasting event was also proposed at the Vilkine Restaurant. Another celebration was planned at the folk culture-oriented Open-Air Museum of Lithuania $(71 \mathrm{~km}$ from Vilnius), where mass was also going to be held at the town church, to be followed by "a traditional blessing of this year's harvest, flowers, and grasses". Also, according to the organisers, "a market was going to be held at the museum, where staff would tell visitors about the healing properties of herb gardens and grasses, and make 'Assumption Day' bouquets' (Andrijauskas 2019).

As can be seen, there was no shortage of events set up for the residents of Vilnius and nearby cities. However, even though this holiday is growing in its entertainment and commercial meanings, these events are capable of drawing only a limited number of people. The question arises, why is "Assumption Day" not a holiday that is suited to be celebrated in city/urban surroundings? According to the data of ethnologist P. Kalnius, who studied weddings held in the Advent and Lent periods in 1977 and 1992, it is the South East regions that are the least secularised in Lithuania; whereas cities are more secular than rural areas (Kalnius 2003: 192-193). This leads us to believe that even now, the Feast of the Assumption is celebrated more widely in provincial, or rural areas. However, as the research showed, the situation is not all that different. My field research conducted in 2017-2018 in villages, a town, and cities near Vilnius, where older people (an absolute majority were aged 50-93; nationalities included Lithuanians, Poles, Russians, Belarusians, Tatars, and Karaims; confessions included Catholics, Orthodox, Old Believers, Muslims, and Karaims; 45 semi-structured interviews) were surveyed, it became apparent that only 45 percent of respondents celebrated the Feast of the Assumption: 29 percent celebrated with their families, 12 percent did so with their friends, and 5 percent with their co-workers. This occasion surprisingly was only celebrated by some respondents from Trakai, where the Feast of the Assumption is marked by a traditional religious celebration. Nor was this day marked by Tatars or Karaims, or older Christians. As a 63-year-old Lithuanian Catholic from Nemenčinė explained, this celebration was held only by his parents and grandparents. Public events to which people were invited through Internet portals attracted only a small portion of inhabitants from the Vilnius surrounds. The essence of the holiday was accurately described by a 56-year-old woman from Trakai: "When the holiday comes around, sometimes it doesn't say to our hearts that 
we need to actually celebrate [it] at all". Summarising the material, it can be said that this holiday was most commonly held in villages in the Vilnius surrounds, by Poles who professed the Catholic faith. Going to the ceremonial mass held at church on this day, followed by feasting with relatives, or family members, served as a special occasion in their ritual year.

\section{Conclusions}

The research revealed how a religious holiday - the Feast of the Assumption embodied different values in different sociocultural surrounds: as a Christian holiday in the late $19^{\text {th }}$ to the first half of the $20^{\text {th }}$ century in Lithuanian villages; as a Lithuanian national holiday in 1929 in Kaunas; as a Lithuanian holiday marked in Punsk (Poland) from 1967; as a non-working day in Vilnius and its surrounds from 2000. The comparison of these meanings leads to the conclusion that even a religious holiday can embody different values in different sociocultural surroundings, ranging from religious, national and ethnic, to simply an excuse for a day off from work. As today's situation in Vilnius shows, and the research conducted in its surrounds, people of different ages and religions, and even from the same location, each have their own understanding of the holiday. This ranges from "a very important and meaningful holiday", to "a day off work without a clear reason as to why it should be celebrated".

Four of the festive episodes show significant changes over time. A religious holiday can take on a national, ethnic, or even commercial attributes. This is evident from the rapid expression of modern culture. Traditions that are created and re-created by ruling structures have no guarantee of being successful. The attempt at combining two national and one religious holiday into "Assumption Day" lasted just one year, 1929, when religious rituals were supplemented with secular rituals. However, a similar attempt in 1969 (without combining separate holidays) in the Punsk area was justified. The celebration enjoys great popularity and draws tourists to this day. Last year, it continued for five days (combining it with the newly formed Bread, Honey, and Milk Festival), and a majority of the events are secular in nature. Attempts are made to give the holiday a similar character in Lithuania as well, however, only a small part of the population of Vilnius and the Vilnius surrounds are informed of the large number of events that are on offer, while during interviews, young people, and often older respondents as well, admit that they do not understand the meaning of the holiday at all. 
All four holidays are related to religious practices and symbols, at the very least they are celebrated according to the Church calendar. However, as the research showed, over time less and less of these remain, with an increase in secular, often also commercial, forms of entertainment that merely seek to attract larger numbers of participants to the celebration. The range of entertainment available however does not always guarantee the holiday's success or the ability of people to grasp its meaning, where a majority simply treat it as another day off from work.

\section{References}

Andrijauskas, Donatas 2019. Kur švęsti Žolines Vilniuje? (Žolinių renginių gidas 2019) [Where to Celebrate the Assumption in Vilnius? (Feast of the Assumption event guide 2019)]. Available at https://madeinvilnius.lt/pramogos/renginiai/ kur-svesti-zolines-vilniuje-zoliniu-renginiu-gidas-2019/, last accessed on 27.01.2020.

Bell, Catherine 1997. Ritual. Perspectives and Dimensions. New York, Oxford: Oxford University Press.

Etzioni, Amitai 2004. Holidays and Rituals: Neglected Seedbeds of Virtue. In: A. Etzioni \& J. Bloom (eds.) We Are What We Celebrate. Understanding Holidays and Rituals. New York and London: New York University Press, pp.1-42.

Fournier, Laurent Sébastien 2019. Traditional Festivals: From European Ethnology to Festive Studies. Journal of Festive Studies, Vol. 1, No. 1, Spring, pp. 11-26.

Kalnius, Petras 2003. Liturginių metų laikų paisymas rengiantis vedyboms kaip konfesinès tapatybès išraiška [Paying Heed to the Liturgical Seasons for Weddings as an Expression of Confessional Identity]. Lietuviu Kataliku Mokslu Akademijos suvažiavimo darbai, Vol. 18, pp. 177-195.

Kpt. Balčiūnas 1939. Tautos šventę bešvenčiant [Celebrating National Day]. Karys, No. 32, p. 531.

Kriaukeniškis 1929. Tautos šventès iškilmès Kaune [Celebrations of National Day in Kaunas]. Lietuvos aidas, 16 August, p. 3.

Marcinkevičienè, Nijolè 1998. Pavarènis [Pavarènis - name of a village in South Lithuania]. Vilnius: Lietuvos liaudies kultūros centras.

Mardosa, Jonas 2004. Pivašiūnų Žolinès atlaidai: 2001 metų etnologinio tyrimo duomenimis [The Festival of the Assumption of the Blessed Virgin in Pivašiūnai: Data of the Ethnological Research of the 2001]. Istorija, Vol. 59-60, pp. 93-112.

Mardosa, Jonas 2007. The Modern Church Festival of the Assumption (Žoline) in Lithuania: Understanding and Motives for Observation. Traditiones, Nr. 36/1, pp. 155-168. 
Mardosa, Jonas 2013. Šventès mieste: keletas kūrimo ir funkcionavimo problemų [Festival in the City: Some Creation and Functioning Problems]. In: J. Mardosa (ed.) Šventès šiuolaikiniame mieste. Festivals in the Modern City. Vilnius: Edukologija, pp. 52-60.

Mardosa, Jonas 2016a. Feast of the Assumption of the Virgin Mary (Žoliné) in the Ethnoconfessionally Mixed Environment of Modern Vilnius. In: G. Stoliarova \& I. Sedakova \& N. Vlaskina (eds.) The Ritual Year 11. Traditions and Trasformation. Kazan-Moscow: T8, pp. 53-66.

Mardosa, Jonas 2016b. Žolinè [Feast of the Assumption]. In: R. Paukštytė-Šaknienè (ed.), Rasa Paukštytė-Šaknienè \& Jonas Mardosa \& Žilvytis Šaknys \& Irma Šidiškienè Šventès šiuolaikineje vilniečiu šeimoje [Holidays in Contemporary Family of Vilnius Inhabitants]. Vilnius: Lietuvos istorijos institutas, pp. 291-311. Paukštytė-Šaknienè, Rasa 2016. Šeima ir kalendorinès šventès sovietinèje Lietuvoje [Family and Calendar Holidays in Soviet Lithuania]. Lietuvos etnologija. Socialines antropologijos ir etnologijos studijos, Vol. 16 (25), pp. 9-34.

Šaknys, Žilvytis Bernardas 2007. Šeimos gyvenimas [Family Life]. Papročiai. Šiaurès Lietuvos kultūros paveldas [Traditions. Cultural Heritage of Northern Lithuania], Vol. 1, pp. 107-136.

Šaknys, Žilvytis 2009. Kultūros transmisijos problema Punsko apylinkèse [Problem of Cultural Transmission in the Area of Punsk]. In: A. Lapinskienè (ed) Etnines kultūros tradiciju tęstinumas ir iššūkiai šiuolaikinèje visuomenejje [Continuity and Challenges of Ethnic Culture Traditions in Modern Society]. Klaipeda: Klaipėdos universiteto leidykla, pp. 87-93.

Šaknys, Žilvytis 2015a. Užgavėnès: Rural and Urban, Religious, Socialist, and Lithuanian Festival of Shrovetide. Folklore: Electronic Journal of Folklore, Vol. 60, pp. 105128. Guest editors Laurent Sébastien Fournier \& Irina Sedakova. doi:10.7592/ FEJF2015.60.shaknys.

Šaknys, Žilvytis 2015b. Karaimų kalendorinès šventės valstybinių švenčių aspektu [Karaim Calendar Holidays in the Context of State Holidays]. Lietuvos etnologija. Socialines antropologijos ir etnologijos studijos, Vol. 15 (24), pp. 99-128.

Šaknys, Žilvytis 2018. Valstybės (Tautos) švenčių formavimo ypatumai 1918-1940 m.Lietuvoje [State(National)HolidaysinLithuaniabetween 1918 and 1940].Lietuvos etnologija: Socialines antropologijos ir etnologijos studijos, Vol. 18 (27), pp. 129-154.

Šaknys, Žilvytis 2019. Draugystè, draugų bendrijų konstravimo ir palaikymo formos mieste [Friendship. The Formation and Maintenance of Communities of Friends in the City]. In: Ž. Šaknys (ed.), Rasa Paukštytė-Šakniene \& Žilvytis Šaknys \& Irma Šidiškienè Vilniečiu socialine squveika ir kultūriné raiška: laisvalaikis, šventes ir ritualai [The Social Interaction and Cultural Expression of Vilnius Residents: Leisure Time, Celebrations and Rituals]. Vilnius: Lietuvos istorijos institutas, pp. 195-281. 
Sirutavičius, Vladas 2001. Šventès nacionalizavimas. “Tautos šventès” atsiradimas Lietuvos Respublikoje XX amžiaus 4-ajame dešimtmetyje [The Nationalization of the Holiday. Emergence of the "National Day" in the Republic of Lithuania in the 1940s]. In: V. Sirutavičius \& D. Staliūnas (eds.) Nacionalizmas ir emocijos (Lietuva ir Lenkija XIX-XX a.) [Nationalism and Emotions (Lithuania and Poland in the $19^{\text {th }}-20^{\text {th }}$ Centuries) ]. Lietuviu atgimimo istorijos studijos, Vol. 17. Vilnius: LII leidykla, pp. 133-145.

Svidinskaitè, Danguolè 2006. Itprastas tikèjimas: religija Punsko krašto žmonių gyvenime [Common Faith: Religion in the Life of People Inhabiting the Punskas Area]. In:

P. Kalnius (ed.) Punsko ir Seinu krašto lietuviai: etninio ir kultūrinio tapatumo bruožai [Lithuanians in the Punsk and Sejny Region: Features of Ethnic and Cultural Identity]. Punskas: “Aušros” leidykla, pp. 238-269.

Tautos šventė [National Day] 1929. Lietuvos aidas, 14 August, p. 1.

Uzdila, Algis 2005. Punsko dienoms nuūžus [After the Days of Punsk]. Aušra, Vol. 17, pp. 18-23.

Vaicekauskiené, Aldona 2004. Žolinè Punske [Feast of the Assumption in Punskas] In: Aldona Vaicekauskienè \& Nastutė Sidarienė \& Romas Vitkauskas Žoliné Punske. Zielna $w$ Puńsku [Feast of the Assumption in Punskas]. Punskas: "Aušros" leidykla, pp. 3-22.

Vyšniauskaitè, Angelè 1993. Mūsų metai ir šventès [Our Years and Holidays]. Kaunas: Šviesa.

Znamierowska-Prüfferowa, Maria 2009. Vilnius, miestas arčiausia širdies [Vilnius, the City is Closest to My Heart]. Vilnius: Alma litera. / Znamierowska-Prüfferowa, Maria 1997. Wilno, miasto sercu naibliższe [Vilnius, the City is Closest to My Heart]. Białystok: Towarzystwo Literackie im. Adama Mickiewicza.

Žolinès Punske [Assumption in Punsk]. Alkas.lt. 2019-08-14 19:00 - 2019-08-18 22:00. Available at http://alkas.lt/renginys/zolines-punske/, last accessed on 27.01.2020.

Žilvytis Šaknys, PhD, Senior Researcher at the Department of Ethnology and Anthropology, Lithuanian Institute of History, Vilnius, Lithuania. He has field works in Lithuania, Byelorussia, Poland, Latvia and Bulgaria. His research interests are in the field of traditional and modern culture, ethnology of youth, ethnology of city, ethnology of friendship, ethnology of tourism, history of ethnology, ethnicity, ethnic and confessional tolerance, ritual year. 